\title{
Soil fauna research in Poland: earthworms (Lumbricidae)
}

\begin{abstract}
Living organisms are the foundation of ecosystem services. Of particular notice is zooedaphone, often underestimated and basically unknown to the general public. The present review summarizes the current state of knowledge related to earthworms occurring in natural and anthropogenically altered habitats in Poland, in the context of the requirement for protection of soil biodiversity.
\end{abstract}

Keywords: earthworms, soil fauna, natural ecosystems, anthropogenic ecosystems

\section{INTRODUCTION}

Advancement of sustainable development and preservation of biological diversity are major tasks faced by the humanity in the $21^{\text {st }}$ century. Announced and supervised by UNESCO, the Decade of Education for Sustainable Development lasted from 2005 to 2014 (Kostecka 2009). Another global environmental and educational operations are to be carried out between 2011 and 2020 in the framework of the Decade of Biodiversity (Strategic Plan... 2011-2020).

Biodiversity is a basis of ecosystem services used by people. All living organisms constitute a foundation of these services, so it is necessary to remember, among others, about soil zooedaphone, which is greatly underestimated, rarely acknowledged, and lacking public awareness (Kostecka 2004, Komisja Europejska... 2010).

Lumbricidae earthworms are a significant part of soil zooedaphone. Their role was recognized in ancient times by Cleopatra and in more contemporary period by Darwin. While making effort to preserve various species of terrestrial plants and animals, do we remember that organisms living in the soil also deserve to be protected? Notably, all soil organisms take part in key processes and changes, crucial for the life on Earth, therefore they constitute an inherent component of all categories of ecosystem services.

An example of multidimensional impacts on the soil and its services is provided e.g. by earthworms which are involved in developing soil structure, in circulation of nutrients and primary production. By improving soil fertility they also significantly impact the quality of crops. According to Blouin et al. (2013) they also play a role in climate regulation, reduction of soil contamination and numerous cultural services. They are a source of nutritious food for animals and, in some cultures, for people. Currently they are also used in environmental biomonitoring. Highly conclusive findings for the needs of bioindicative measurements can be acquired e.g. by analyzing the number of Lumbricidae species and communities in relevant ecosystems.

The review conducted for the needs of this article focused on studies investigating qualitative and quantitative characteristics of this very significant group of soil inhabitants in the world and in Poland. This is important from the viewpoint of efforts designed to assess the quality and protect biodiversity of the soil - component of the natural environment.

\section{METHODS}

Analysis of the rate of worldwide research focusing on the selected issues (particularly related to Lumbricidae) was based on the data from Science Direct which is a full-text database created by Elsevier Science publishing company and comprising electronic versions of Elsevier scientific periodicals. Specific key words (soil biodiversity, soil fauna, Lumbricidae reclamation) were entered into the database search engine, and the result was counted, after retrieving the reports related to a given subject published in the last twenty years (2014 data included relevant information up until September of this year).

Source materials and a list of publications by Polish authors provided information for identifying the range of subjects investigated by studies focusing on earthworms in the domestic natural and anthropogenic ecosystems. 


\section{STUDIES OF LUMBRICIDAE ACCORDING TO SCIENCE DIRECT DATA}

Analysis of Science Direct database shows that, globally, since 1996 the number of publications related to earthworms has decreased and remains at a relatively low level (Fig. 1 and 2). In comparison to studies focusing on soil biodiversity (Fig. 1) or those containing a wide range of genetic analyses (Table 1), the number of publications related to Lumbricidae is very low and definitely insufficient.

\section{STATE OF RESEARCH FOCUSING ON EARTHWORMS IN NATURAL AND ANTHROPOGENIC ECOSYSTEMS IN POLAND}

The current state of knowledge related to earthworms in Poland is unsatisfactory for both natural and anthropogenic ecosystems. Studies of Lumbricidae are frequently of historical nature or focus on small parts of the territory of Poland. Knowledge of some species is based only on isolated sites, which may

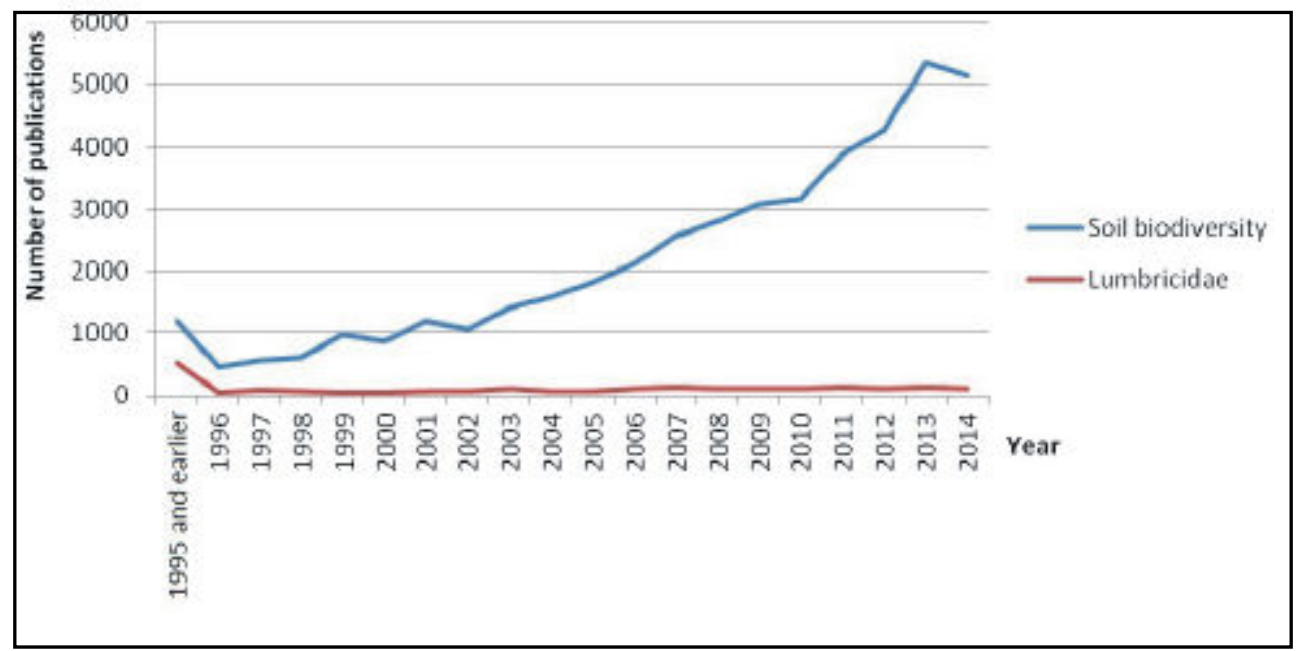

FIGURE 1. Number of publications matching the phrases 'soil biodiversity' and 'Lumbricidae' according to Science Direct database

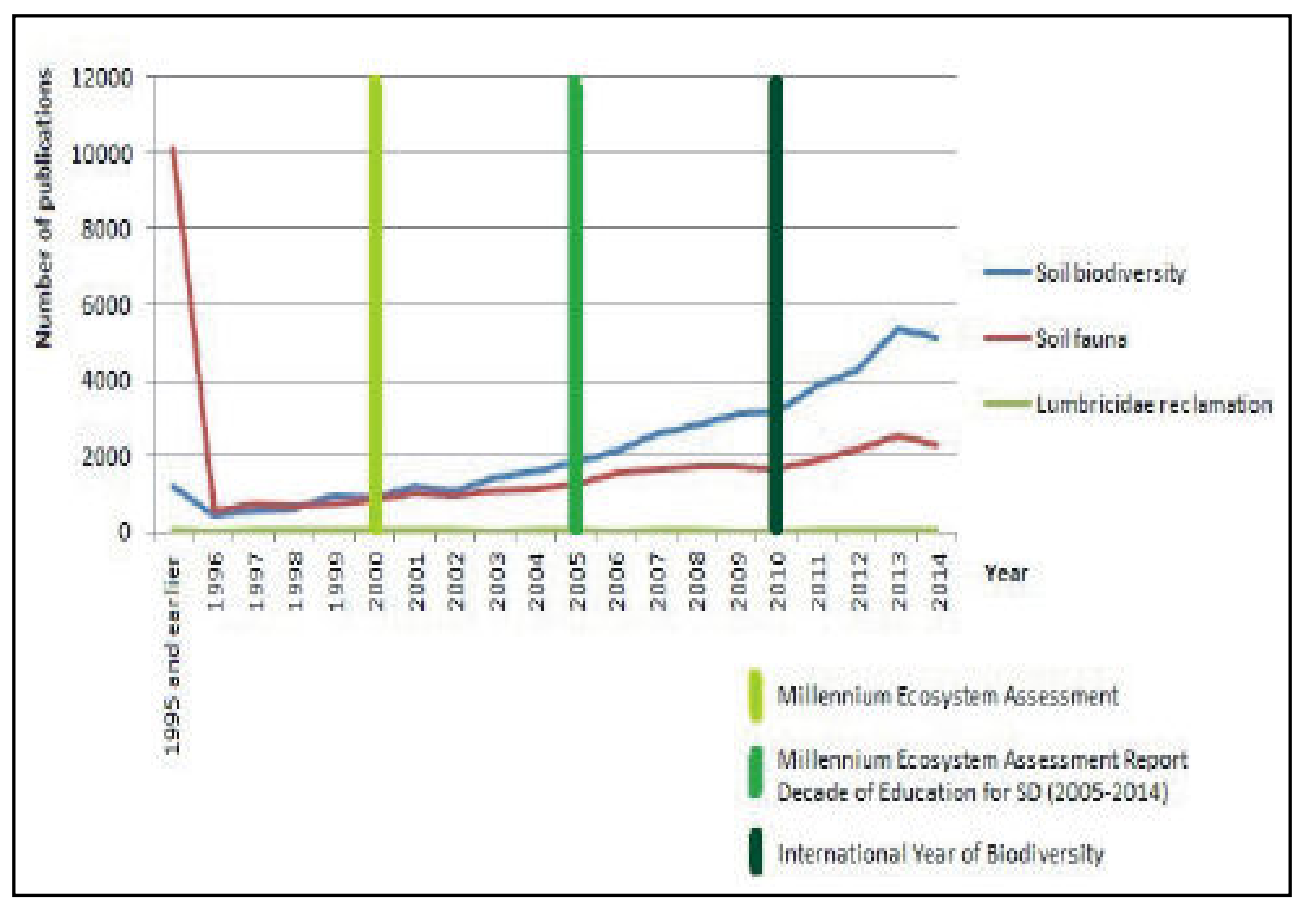

FIGURE 2. Number of publications matching the phrases 'soil biodiversity' and 'Lumbricidae reclamation' with reference to international environmental campaigns (Science Direct database) 
TABLE 1. Number of publications matching the phrase Lumbricidae compared to genetic research (Science Direct database)

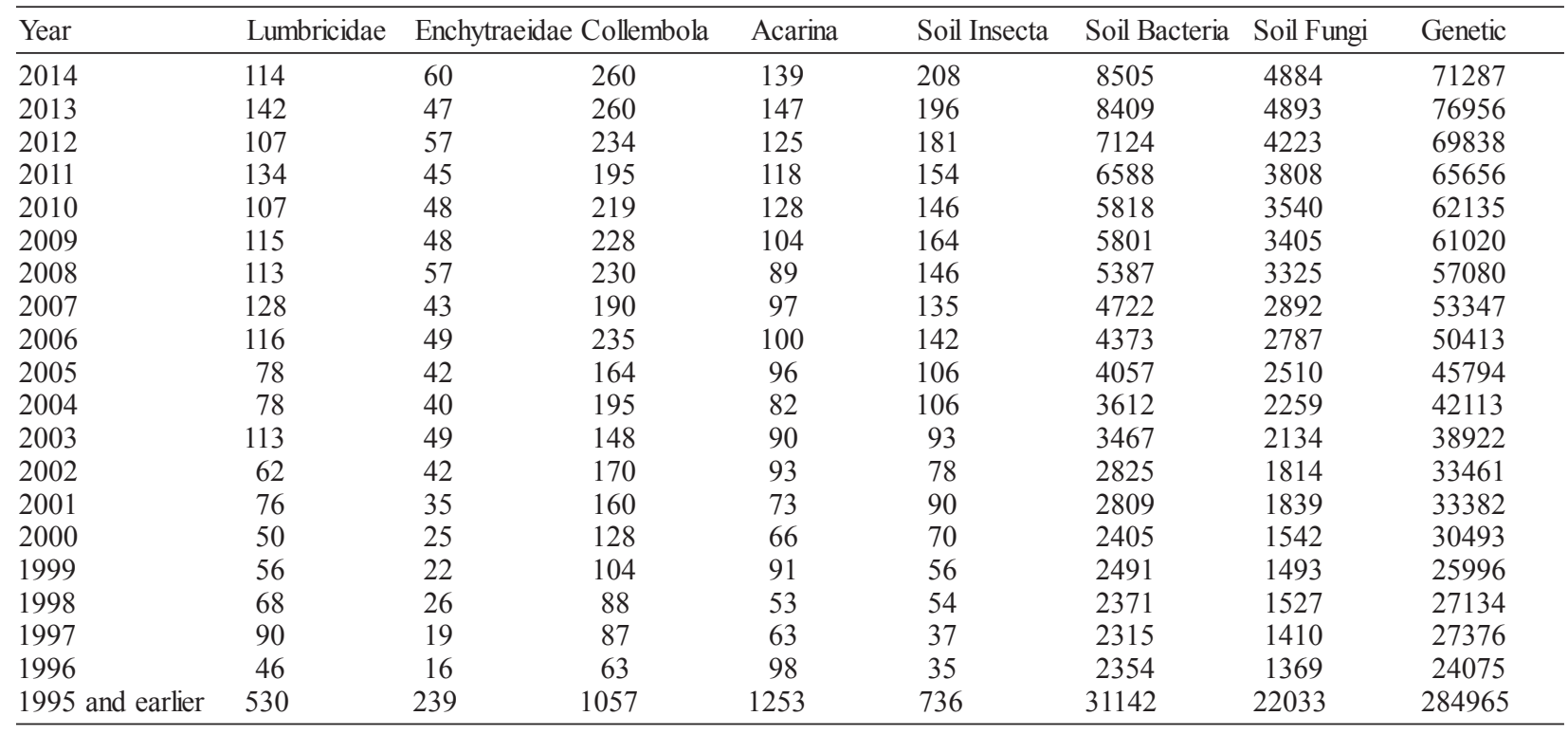

result from the insufficient fauna-related data. Therefore, due to the changes occurring in the environment it is indispensable to both repeat and expand the previously conducted observations. It is also necessary to supplement findings by conducting research in areas in which Lumbricidae fauna has never been investigated before, e.g. areas of some national parks, nature reserves and habitats with varied wildlife (Kasprzak 1986, 2004).

Basic information about Lumbricidae communities in the Kampinos National Park (middle Poland) can be found in a publication by Plisko (1969). She also investigated the diversity of Lumbricidae in the isle of Wolin (Plisko 1962) and in the Bieszczady mountains (Plisko 1971, 1973). Another studies provided data about earthworms in the Pieniny mountains (Kasprzak 1979, 2000) and in the Polish part of the Carpathians (Kasprzak 1989). On the other hand, Rożen (1982, 1988) investigated Lumbricidae populations in the Niepołomice Forest (south Poland) and in the woods of the Beskid Śląski (Rożen et al. 2013). Studies focusing on various areas of Carpathian beech forests in the Bieszczady mountains were conducted by Kostecka (1992a, 1992b, 1998). Furthermore, comprehensive characteristics of the species inhabiting the Western Bieszczady mountains can be found in publication by Dumnicka and Kostecka (2004).

It is also necessary to conduct more comprehensive studies in areas affected by human activity (farming fields, meadows, wastelands, urban and post-industrial areas). Meanwhile, research focusing on farming areas may draw on previous studies carried out by e.g. Kasprzak and Ryl (1978), Kasprzak and Volender (1988),
Witkowski (1983, 1985), and Kostecka and Mazur (2009).

Earthworms inhabiting urban and suburban areas were investigated, among others, by Plisko (1959) and Pilipiuk (1981). Studies in the vicinity of Rzeszów city were conducted by Garczyńska and Kostecka (2002).

There are few publications focusing on earthworms in severely degraded and post-industrial areas (frequently encountered in Polish landscape). Such studies were conducted e.g. in Jeziórko in reclaimed areas formerly holding Machów sulphur plant (Kostecka et al. 2004), in the area previously occupied by Solvay sodium production plant in Kraków city (Pośpiech and Skalski 2006), in the area of Bolesław Zn-Pb steelworks (Łapiński and Rościszewska 2003), and in the areas contaminated with heavy metals near Olkusz (Tomsza et al. 2010).

In Europe there are a few centers specializing in Lumbricidae research. Their studies have a long history e.g. in Great Britain (Butt 2008; Butt and Lowe 2003; Carpenter et al. 2012). Lumbricofauna has been extensively investigated e.g. in Romania (Pop 1997; Pop and Pop 2006; Pop et al. 2007), France (Deacaens et al. 2008; Richard et al. 2012), and in the Balkans (Stojanović and Karaman 2005; Stojanović et al. 2008; Stojanović et al. 2012).

\section{PRESERVATION OF EARTHWORM DIVERSITY}

Earthworm species protection and related issues have been rarely explored so far. In the Balkan 
Peninsula a special Red List of endangered species was created for them, defining hazard categories (Stojanović et al. 2008). In Great Britain and Ireland distribution of Lumbricidae species has been presented in a form of maps (Carpenter et al. 2012). However, the study is incomplete due to numerous gaps in geographic distribution of some species. Therefore, even in England, where wide ranging attempts have been made to create an inventory, it is necessary to continue operations and monitor earthworm populations in the relevant areas.

In Poland, no earthworm species have been entered onto lists of endangered and protected animals. This is frequently linked with a lack of sufficient fauna-related data and the resulting inability to define hazards pertaining to these invertebrates. Hence it is impossible to classify specific Lumbricidae species in accordance with European Red List categories, defined e.g. by the International Union for Conservation of Nature (2001).

Notably, in Poland there are a few endemic species, encountered only in the Carpathians. Oligoporeutic earthworms constitute $48 \%$ of the 21 species identified in the Western Bieszczady mountains (Dumnicka and Kostecka 2004).

The existing evidence shows that hazards related to earthworm fauna result mainly from damage or loss of their natural habitats. This is a result of land development, intensive agrotechnical engineering, damage to plant litter, transformation of forests into farming fields and meadows, as well as land drainage (Kasprzak 2004).

\section{CONCLUSIONS}

1. The analysis of source materials shows that, although earthworms significantly contribute to the quality of ecosystem services, in Poland there are relatively few wide-ranging environmental studies focusing in this group of soil invertebrates.

2. Compared with efforts to preserve Lumbricidae taken in other countries, related operations carried out in Poland are insignificant.

\section{REFERENCES}

Blouin M., Hodson M.E., Delgado E.A., Baker G., Brussaard E., Butt K.R., Dai J., Dendooven L., Peres G., Tondoh J.E., Cluzeau D., Brun J.J., 2013. A review of earthworm impact on soil function and ecosystem services. European Journal of Soil Science, 64: 161-182.

Butt K.R., 2008. Earthworms in soil restoration: lessons learnt from UK case studies of land reclamation. Restoration Ecology, 16: 637-641.

Butt K.R., Lowe C., 2003. Earthworm Research Group (Electronic document: http://www.uclan.ac.uk/research/environment/ groups/earthworm_research_group.php, date of enter 09.12.2013).
Carpenter D., Sherlock E., Jones D.T., Chiminoides J., Writer T., Neilson R., Boag B., Keith A.M., Eggleton P., 2012. Mapping of earthworm distribution for the British Isles and Eire highlights the under-recording of an ecologically important group. Biodiversity and Conservation, 21: 475-485.

Deacaëns T., Margerie P., Aubert M., Hedde M., Bureau F., 2008. Assembly rules within earthworm communities in North-Western France: A regional analysis. Applied Soil Ecology, 39(3): 321-335.

Dumnicka E., Kostecka J., 2004. Przegląd skąposzczetów (Oligochaeta) i pijawek (Hirudinea) Bieszczadów. Monografie Bieszczadzkie, 7: 15-28 (in Polish with English abstract).

Garczyńska M., Kostecka J., 2002. Earthworms in chosen antropogenic environments. Bicnik, 2: 145-150.

International Union for Conservation of Nature 2001 (Electronic document: http://www.iucnredlist.org/technical-documents/ categories-and-criteria/2001-categories-criteria, date of enter 27.07.2015).

Kasprzak K., 1979. Skąposzczety (Oligochaeta) Pienin. III. Dżdżownice (Lumbricidae). Fragmenta Faunistica, 24: 8195 (in Polish with English abstract).

Kasprzak K., 1986. Skapposzczety glebowe III. Rodzina Dżdżownice (Lumbricidae). Klucz do oznaczania bezkręgowców Polski. Wydawnictwo Naukowe PWN, Warszawa: 187 pp.

Kasprzak K., 1989. Zoogeography and habitat distribution of earthworms (Lumbricidae) and enchytraeids (Enchytraeidae) of the Carpathian Mountains (Poland). Miscellania Zoologica, 13: 37-44.

Kasprzak K., 2000. Skaposzczety (Oligochaeta). [In:] Flora i fauna Pienin. (red.) Razowski J. Monografie pienińskie. Krościenko nad Dunajcem, 1: 93-100.

Kasprzak K., 2004. Przemiany fauny Skąposzczetów (Oligochaeta) środowisk lądowych, ich zagrożenia i możliwość ochrony. Zeszyty Problemowe Postępów Nauk Rolniczych, 498: 103-110 (in Polish with English abstract).

Kasprzak K., Ryl B., 1978. Wpływ gospodarki rolnej na występowanie skaposzczetów (Oligochaeta) w glebach pól uprawnych. Wiadomości Ekologiczne, 4: 333-366.

Kasprzak K., Volender M., 1988. Wpływ nawożenia gleby gnojowicą i fosfogipsem na zagęszczenie dżdżownic (Oligochaeta, Lumbricidae). Zeszyty Naukowe AR w Szczecinie, 124: 81-90 (in Polish with English abstract).

Komisja Europejska: Fabryka życia. Dlaczego różnorodność biologiczna gleby jest tak istotna? 2010. Urząd Publikacji Unii Europejskiej. Luksemburg, (Electronic document: http://ec.europa.eu/environment/soil/pdf/soil_biodiversity_ brochure_pl.pdf, date of enter 13.08.2014).

Kostecka J., 1992a. Dżdżownice (Lumbricidae, Oligochaeta) połoniny Wetlińskiej i Olszynki (Alnetum incanae carpaticum) w okolicy Ustrzyk Górnych w Bieszczadach Zachodnich. Nauk. Prace Rolnicze i Leśne. Przyrodnicze Podstawy Produkcji Rolniczej, 1: 58-63 (in Polish with English abstract).

Kostecka J., 1992b. Dżdżownice (Lumbricidae, Oligochaeta) zidentyfikowane w niektórych punktach Bieszczadów Zachodnich. Zeszyty Naukowe Prace Rolnicze i Leśne. Przyrodnicze Podstawy Produkcji Rolniczej, 1: 110-118 (in Polish with English abstract).

Kostecka J., 1998. Earthworm (Oligochaeta, Lumbricidae) communities in some natural sites in the Bieszczady Mts. (SouthEastern Poland)". [In:] Soil Zoological Problems in Central Europe. (reds.) Pizl V., Tajovsky K. Ceske Budejovice: 93-101. 
Kostecka J., 2004. Preservation of soil fauna biodiversity - still undervalued in education for sustainable development. in: Using, choosing or creating the future. V.W. Thoresen (ed.). Hř gskolen i Hedmark Oppdragsrapport, 4: 209-220.

Kostecka J., 2009. Dekada edukacji dla zrównoważonego rozwoju - wizja, cel, strategia. Problemy ekorozwoju, 2: 101106 (in Polish with English abstract).

Kostecka J., Mazur A., 2009. Cechy przedstawicieli fauny dżdżownic (Lumbricidae) w odłogu piaszczystym rekultywowanym osadami ściekowymi. Zeszyty Problemowe Postępów Nauk Rolniczych, 535: 243-251 (in Polish with English abstract).

Kostecka J., Pączka G., Mastalerczyk A., 2004. Ocena procesu rekultywacji terenów po kopalni siarki w Jeziórku na podstawie stanu fauny dżdżownic. Zeszyty Problemowe Postępów Nauk Rolniczych, 498: 135-145 (in Polish with English abstract).

Łapiński S., Rościszewska M., 2003. Różnice w kumulacji metali ciężkich Lumbricus rubellus (Hoffm.) i Dendrobaena octaedra (Sav.). Roczniki Naukowe Zootechniki Suplement, 17: 751-754 (in Polish with English abstract).

Pilipiuk I., 1981. Earthworms (Oligochaeta, Lumbricidae) of Warsaw and Mazowia. Memorabilia. Zoologia, 34: 69.

Plisko J.D., 1959. Lumbricidae Warszawy i okolic. Fragmenta Faunistica, 8: 247-271 (in Polish with English abstract).

Plisko J.D., 1962. Lumbricidae (Oligochaeta) wyspy Wolin. Fragmenta Faunistica, 10: 11-26 (in Polish with English abstract).

Plisko J.D., 1969. Materiały do poznania ekologii dżdżownic (Oligochaeta, Lumbricidae) Kampinowskiego Parku Narodowego. Fragmenta Faunistica, 15: 291-307 (in Polish with English abstract).

Plisko J.D., 1971. Dżdżownice (Oligochaeta, Lumbricidae) Bieszczadów. Fragmenta Faunistica, 17: 31-48 (in Polish with English abstract).

Plisko D.J., 1973. Lumbricidae dżdżownice (Annelida: Oligochaeta). Fauna Polski 1. PWN, Warszawa: 156 pp.

Pop V.V., 1997. Earthworm-vegetation-soil relationships in the Romanian Carpathians. Soil Biology \& Biochemistry, 29: 223-229.

Pop V.V., Pop A.A., 2006. Lumbricid earthworm invasion in the Carpathian Mountains and some other sites in Romania. Biological Invasions Belowground, 8: 1219-1222.

Pop V.V., Pop A.A., Csuzdi C., 2007. An updated viewpoint on the earthworm communities with the Dendrobaena alpina species group (Oligochaeta, Lumbricidae) from the SouthEastern Carpathians. European Journal of Soil Biology, 43: $53-56$.

Pośpiech N., Skalski T., 2006. Factors influencing earthworm communities in post-industrial areas of Krakow Soda Works. European Journal of Soil Biology, 42: 278-283.
Richard B., Legras M., Margerie P., Mathieu J., Barot S., Caro G., T., Dubs F., Dupont L., Decaens T., 2012. Spatial organization of earthworm assemblages in pastures of northwestern France. European Journal of Soil Biology, 53: 62-69.

Rożen A., 1982. The annual cycle in populations of earthworms (Lumbricidae, Oligochaeta) in three types of oak-hornbeam of the Niepołomicka Forest I. Species composition, dominance, frequency and associations. Pedobiologia, 23: 199-208.

Rożen A., 1988. The annual cycle in populations of earthworms (Lumbricidae, Oligochaeta) in three types of oak-hornbeam of the Niepołomicka Forest II. Species composition, dominance, frequency and associations. Pedobiologia, 31:169-178.

Rożen A., Mysłajek R.W., Sobczyk Ł., 2013. Altitude versus vegetation as the factors influencing the diversity and abundance of earthworms and other soil macrofauna in montane habitat (Silesian Beskid Mts, Western Carpathians). Polish Journal of Ecology, 61 (1): 145-156.

Stojanović M., Karaman S., 2005. Distribution of two species of the earthworm fauna of Sumadija (Serbia) in the Balkans and neighboring territories. Archives of Biological Science, 5: 133136.

Stojanović M., Milutinović T., Karaman S., 2008. Earthworm (Lumbricidae) diversity in the Central Balkans: An evaluation of their conservation status. European Journal of Soil Biology, 44: 57-64.

Stojanović M., Tsekova R., Milutinović T., 2012. Earthworms (Oligochaeta: Lumbricidae) of Bulgaria: Diversity and Biogeographical Review. Acta Zoologica Bulgarica, 4: 7-15.

Strategic Plan for Biodiwersity 2011-2020. (Electronic document: http://www.cbd.int/decision/cop/?id=12268, date of enter 27.11.2014)

Tomsza E., Dumnicka E., Niklińska M., Rożen A., 2010. Enchytraeid and earthworms communities along a pollution gradient near Olkusz (southern Poland). European Journal of Soil Biology, 46: 218-224.

Witkowski T., 1983. Density and biomass of earthworms (Lumbricidae) under conditions of a short crop rotation cycle. Roczniki Gleboznawcze - Soil Science Annual, 34(1/2): 85-102 (in Polish with English abstract).

Witkowski T., 1985. Differentiation of number and biomass of earthworms in alfalfa in two types of farms. Roczniki Gleboznawcze - Soil Science Annual, 36(4): 65-73 (in Polish with English abstract).

Received: April 10, 2015

Accepted: July 29, 2015

\section{Badania fauny glebowej w Polsce - dżdżownice (Lumbricidae)}

Streszczenie: Podstawę świadczeń pełnionych przez ekosystemy stanowią organizmy żywe. Na szczególną uwagę zasługuje zooedafon, często niedoceniany i nieobecny w świadomości społecznej. Opracowano zestawienie aktualnego stanu wiedzy nad dżdżownicami środowisk naturalnych i antropogenicznie zmienionych w warunkach Polski w kontekście potrzeby ochrony różnorodności biologicznej gleb.

Słowa kluczowe: dżdżownice, fauna glebowa, ekosystemy naturalne, ekosystemy antropogeniczne 